Zagazig J. Agric. Res., Vol. 43 No. (4) 2016

http:/www.journals.zu.edu.eg/journalDisplay.aspx?Journalld=1\&queryType=Master

\title{
IN VITRO RELATIONSHIP BETWEEN ORGANOGENESIS FROM Datura metel L. ANTHER AND CATALASE ACTIVITY
}

\author{
Siham A. Salim* \\ P1. Prod. Dept., Tech. Coll., Al-Musaib, Al-Furat Al-Awsat, Tech. Univ., Al Iraq
}

\begin{abstract}
The aim of the present study was to investigate the effect of different concentrations of plant growth regulators on in vitro induction of callus and plantlets regeneration from anthers culture of Datura metel L. The activity of catalase (CAT) as one of the important antioxidant enzymes was measured during different stages of callus and organogenesis under all combinations of hormones. Anthers were cultured under aseptic conditions on Murashige and Skoog (MS) medium supplemented with benzyladenine (BA) $(0.0,3.0,5.0$ and $7.0 \mathrm{mg} / \mathrm{l})$ in combination with 2,4-D (2,4-dichlorophenoxy acetic acid) $(0.0,0.01$ or $0.05 \mathrm{mg} / \mathrm{l})$ for callus induction and organogenesis. Results showed that MS containing different combinations of BA and 2,4-D induced calli with percentage ranging between 20$100 \%$. High concentrations of growth regulators enhanced the highest callus percentage and promoted plantlets regeneration by indirect organogenesis reached to higher numbers of regenerated plantlets (4.5 and 7.4) at $5.0 \mathrm{mg} / 1 \mathrm{BA}+0.05 \mathrm{mg} / 1$ 2,4-D and $7.0 \mathrm{mg} / 1 \mathrm{BA}+0.05 \mathrm{mg} / 1$ 2,4-D, respectively. Results revealed that catalase activity increased significantly in organogenic callus with regenerated plantlets (23.5 and 47.3 unit) at higher concentrations of BA and 2,4-D (5.0 mg/l BA + $0.05 \mathrm{mg} / 1$ 2,4-D and $7.0 \mathrm{mg} / 1 \mathrm{BA}+0.05 \mathrm{mg} / 1$ 2,4-D, respectively).
\end{abstract}

Key words: Organogenesis, anther culture, Datura metel L., catalase activity, in vitro culture.

\section{INTRODUCTION}

The Solanaceae family contains many important plants. Datura metel L. is one of the pharmaceutical plants belonging to this family that produces secondary metabolites such as alkaloids (Sato et al., 2001; Murch et al., 2009). Plant tissue culture technique induce plants to produce secondary metabolites under controlled conditions (Gumuscu et al., 2008), or as an efficient method for propagation of many plants using various explants by either shoot proliferation and multiplication from shoot tip and nodal explants (Shahsavari et al., 2010; Ibrahim et al., 2013; Martins et al., 2015), or organogenesis in many plant species (Sudhersan and Hussain, 2003; Radhika et al., 2006; Selvaraj et al., 2006; Mannan et al., 2013). Anther culture technique is one of these methods, which has been successful in many plants. Through this method, the production of

\footnotetext{
* Corresponding author: Tel. : +9647804660167

E-mail address: dr.sihamabdalrazzaq@yahoo.com
}

homozygous doubled haploids can be achieved in short period that made it useful in plant breeding (Nurhidayah et al., 1996; Kadota and Niimi, 2004).

Plant cells secreted many antioxidant enzymes which are different in their nature and function according to the type of oxidation. These enzymes can play an important role in controlling of reactive oxygen species (ROS) that causing damages to plant cells (Blokhina, 2000). Catalase (CAT) is one of these important defending enzymes in plant tissues, it works on hydrogen peroxide $\left(\mathrm{H}_{2} \mathrm{O}_{2}\right)$ that resulted from the cellular metabolism processes and converts it to water and oxygen molecules (Willekens et al., 1997).

The aim of this study is to induce callus and organogenesis from Datura metel L. anther and to survey the changes in Catalase activity during these processes. 


\section{MATERIALS AND METHODS}

\section{Preparation, Sterilization and Culture of Explants}

Flower buds were collected from Datura metel L. plants. In the laboratory, they were immersed in ethanol (96\%) for 10 minutes for surface sterilization, then rinsed with sterilized distilled water for 3 minutes. The buds were transferred to a sterile Petri dish and were split open using a blade and the anthers were excised under aseptic conditions without damage and the filaments were removed, then anthers were cultured horizontally (Fig. 1) on Murashige and Skoog (MS) medium (Murashige and Skoog, 1962), supplemented with BA (0.0, $3.0,5.0$ or $7.0 \mathrm{mg} / \mathrm{l}$ ) alone or in combination with $2,4-\mathrm{D}(0.0,0.01$ or $0.05 \mathrm{mg} / \mathrm{l})$ to induce callus and organogenesis. Cultures were incubated in growth room under controlled conditions $\left(25 \pm 2^{\circ} \mathrm{C}\right.$ and $1000 \mathrm{Lux}$ for $16 \mathrm{hr}$., photoperiod). Ten replicates were used for each treatment (in each replicate, three anthers were cultured). Experiments were repeated two times. The frequency of callus induction (\%) from anthers was measured according to Zaidi et al. (2006) formula:

Frequency of callus induction $(\%)=$

No. of anthers induced callus

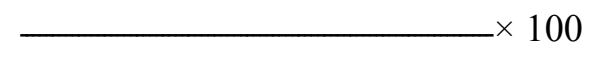

No. of cultured anthers

The number of regenerated plantlets were calculated after 45 days from culture.

\section{Estimation of Catalase activity}

The reaction solutions were prepared according to Whitaker (2003) as follows: a) Phosphate buffer $(50 \mathrm{mM})$ : (1) Dissolve $6.81 \mathrm{~g} \mathrm{KH}_{2} \mathrm{PO}_{4} \cdot 2 \mathrm{H}_{2} \mathrm{O}$ in water and make to 1L. (2) Dissolve $8.90 \mathrm{~g} \mathrm{Na} \mathrm{NaPO}_{4} \cdot 2 \mathrm{H}_{2} \mathrm{O}$ in water and make to $1 \mathrm{~L}$. Mix solutions (1) and (2) in proportion of 1:1.5 $(V / V), \mathrm{pH}$ 7.0.

b) Hydrogen Peroxide $\left(\mathrm{H}_{2} \mathrm{O}_{2} 30 \mathrm{mM}\right)$ : Dilute $0.34 \mathrm{ml}$ of $30 \% \mathrm{H}_{2} \mathrm{O}_{2}$ (freshly opened) with phosphate buffer, pH 7.0 (above) to $100 \mathrm{ml}$ (smaller volumes of reagents can be prepared by keeping the concentrations constant as given).

c) Sample of catalase : prepared in the $50 \mathrm{mM}$, pH 7.0 Phosphate buffer.

Catalase activity was assayed from the hydrogen peroxide decomposition rate as measured by the decrease of absorbance at $240 \mathrm{~nm}$, and the activity of enzyme calculated according to the following equation (Frary et al., 2010):

Ctalase activity (unit) $=\frac{\Delta \mathrm{Abs} / \mathrm{min} \times \text { reaction volume }}{0.001}$

Where :

$\Delta \mathrm{Abs}$ : the difference in absorbance.

reaction volume: final volume of reaction sample in cuvette.

min : reaction time.

0.001: is the enzyme quantity that causing change in absorbance in $1 \mathrm{~min}$.

\section{Statistical Analysis}

Data were analyzed using completely randomized design (CRD) and means were compared using the least significant difference (LSD) at 0.05 (GentSas, 2007).

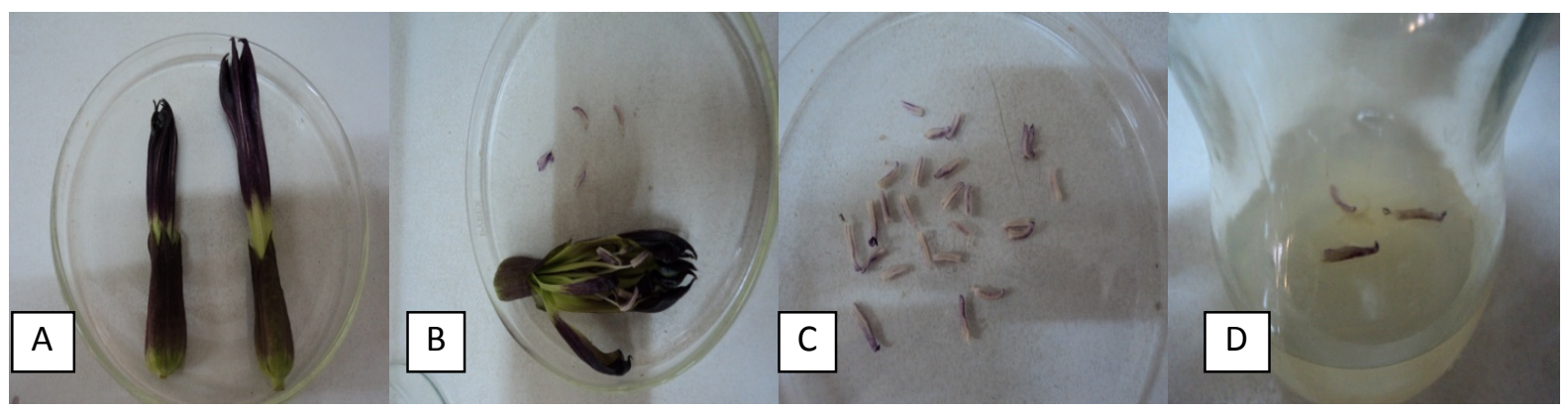

Fig. 1. Process of excised and cultured of Datura metel L. anthers. (A) flower buds. (B,C) excised of anthers. (D) anthers cultured on MS medium 


\section{RESULTS AND DISCUSSION}

\section{Callus Induction}

Results in Table 1 and Fig. 2 show differences in callus induction frequency from anthers between BA and 2,4-D concentrations. BA gave the best callus induction percentages (76.7 and $83.3 \%$ ) at 5.0 and $7.0 \mathrm{mg} / \mathrm{l}$, respectively. Results show also that MS supplemented with 2,4-D at 0.01 and $0.05 \mathrm{mg} / 1$ was most effective in callus induction ( 85.0 and $90.0 \%$, respectively) as compared with the control. The percentage of anthers that forming callus was significantly higher $(100 \%)$ on MS medium supplemented with BA $5.0 \mathrm{mg} / 1+0.01 \mathrm{mg} / 1$ 2,4-D, $5.0 \mathrm{mg} / 1$ $\mathrm{BA}+0.05 \mathrm{mg} / 1$ 2,4-D, $7.0 \mathrm{mg} / 1 \mathrm{BA}+0.01 \mathrm{mg} / \mathrm{l}$ 2,4-D and $7.0 \mathrm{mg} / 1 \mathrm{BA}+0.05 \mathrm{mg} / \mathrm{l} 2,4-\mathrm{D}$ as compared with control (since the MS basal medium alone did not form callus on anthers). Previous studies indicated that plant hormones played an important role in callus induction from different explants, and the best response different according to the original plant species and the type of explants that used in tissue culture (Brasileiro et al., 1999; Alagumanian et al., 2004; Ibrahim et al., 2012; Mannan et al., 2013).

\section{Plantlets Regeneration from Callus}

After the formation of callus on anthers under different concentrations of growth regulators; indirect organogenesis from callus was occurred in the same combinations of BA and 2,4-D (Table 2). Within 45 days of culture, green swellings appeared on the surface of callus, then, these swellings were regenerated to plantlets (Fig. 3). As results in Table 2, the maximum mean number of plantlets (4.83) was obtained on medium containing $7.0 \mathrm{mg} / \mathrm{L}$ BA that was significantly higher compared with other BA concentrations. The presence of cytokinins is necessary for regeneration, so the treatments that lack of BA did not induce any regeneration response. Researchers found that addition of cytokinins in suitable concentrations could be stimulate shoot or bud formation from callus (Kaviani et al., 2011).

Plantlets regeneration was occurred also in 2,4-D concentrations in which the highest significant number of regenerated plantlets $(3.80$ plantlets) was recorded with $0.05 \mathrm{mg} / 1$ as compared with other concentrations. There were significant differences in regeneration when MS medium containing different combinations of BA and 2,4-D. In general, the maximum number of regenerated plantlets (7.40) was obtained in $\mathrm{MS}+7.0 \mathrm{mg} / 1 \mathrm{BA}+0.05 \mathrm{mg} / 1$ 2,4-D comparing with other interactions whereas the control, MS $+0.01 \mathrm{mg} / 1$ 2,4-D and MS + $0.05 \mathrm{mg} / 1$ 2,4-D did not induce any morphogenic responses and they grown in randomly pattern. Mishra et al. (2006) reported that non-organogenic callus grows in unorganized manner, but the organogenic callus grows very fast and gives rise to multiple shoots or buds. Cytokinins and auxins are usually known to promote the formation of callus and shoots in many excited and in vitro cultured explants. Proper type and concentration of these growth regulators are different for each plants and explants (Jain and Ochatt, 2010; Mannan et al., 2013).

\section{Catalase Activity}

Catalase activity changes according either to the physiological status of plant cells or to the composition of medium specially hormones. Results in Table 3 show that there was gradual increasing in the enzyme activity with the increasing of BA concentration reaching to 20.0 units at $7.0 \mathrm{mg} / 1 \mathrm{BA}$. Significant increasing in activity was occurred with 2,4-D concentrations in which the highest concentration $(0.05 \mathrm{mg} / \mathrm{l})$ gave the maximum activity of enzyme which was 20.9 units.

The interaction results show that the organogenic callus with regenerated plantlets on MS medium supplemented with $7.0 \mathrm{mg} / 1 \mathrm{BA}+$ $0.05 \mathrm{mg} / 1$ 2,4-D, $5.0 \mathrm{mg} / 1 \mathrm{BA}+0.05 \mathrm{mg} / 1$ 2,4-D, $7.0 \mathrm{mg} / 1 \mathrm{BA}+0.01 \mathrm{mg} / 12,4-\mathrm{D}$ and $3.0 \mathrm{mg} / 1 \mathrm{BA}$ $+0.05 \mathrm{mg} / 12$ 2,4-D gave the maximum catalase activities (47.3, 23.5, 12.1 and 12.5 units, respectively) followed by organogenic callus only as compared with other interactions, whereas the control showed the lowest activity due to no callus was induced on it. The changes in catalase activity may be due to the synthesis of amino acids that required for the synthesis of this important antioxidant enzyme and certain proteins that required for callus proliferation and to initiate shoots or buds or roots formation (Palai et al., 2000 ; Tian et al., 2003; Konieczy et al., 2014). 
Table 1. Influence of different concentrations of $B A$ and 2,4-D (mg/l) in MS medium on callus induction frequency (\%) from anthers of Datura metel. L

\begin{tabular}{|c|c|c|c|c|}
\hline $2,4-\mathrm{D}(\mathrm{mg} / \mathrm{l})$ & 0.0 & 0.01 & 0.05 & Mean of BA \\
\hline \multicolumn{5}{|l|}{ BA (mg/l) } \\
\hline 0.0 & 0.0 & 60.0 & 70.0 & 43.3 \\
\hline 3.0 & 20.0 & 80.0 & 90.0 & 63.3 \\
\hline 5.0 & 30.0 & 100.0 & 100.0 & 76.7 \\
\hline 7.0 & $50.0 \quad 50.0$ & 100.0 & 100.0 & 83.3 \\
\hline Mean of 2,4-D & 25.0 & 85.0 & 90.0 & \\
\hline LSD (0.05) & $\mathrm{BA}=17.89$ & $2,4-\mathrm{D}=15.50$ & & $-D=30.99$ \\
\hline
\end{tabular}
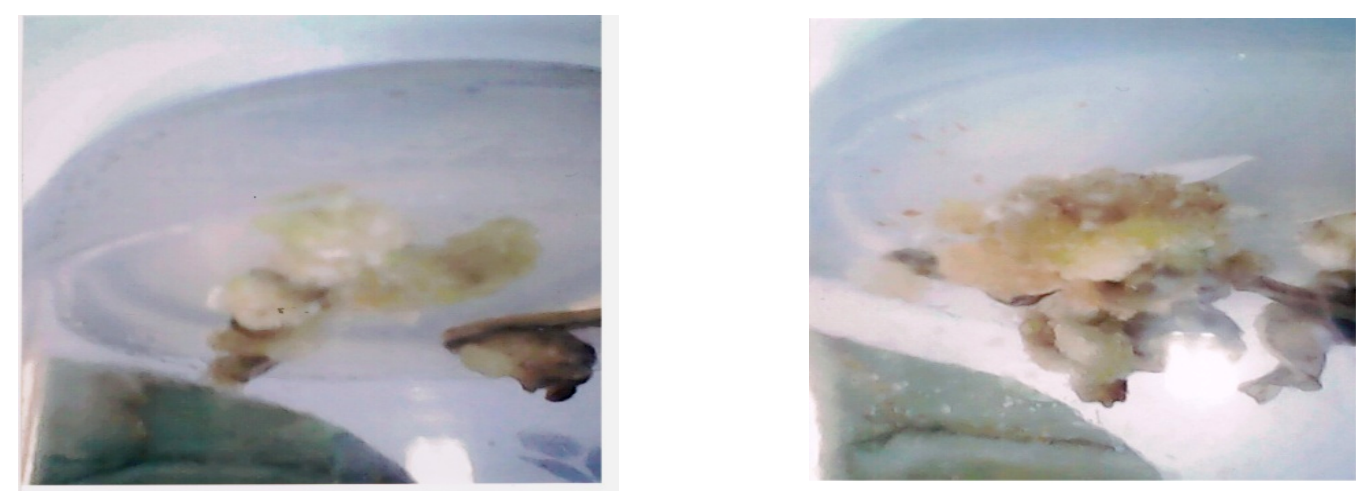

Fig. 2. Formation of callus on anthers cultured on MS medium supplemented with different concentrations of $\mathrm{BA}$ and 2,4-D.

Table 2. Influence of different concentrations of BA and 2,4-D (mg/l) in MS medium on number of regenerated plantlets from callus anthers of Datura metel. $\mathrm{L}$.

\begin{tabular}{|c|c|c|c|c|c|}
\hline & $2,4-\mathrm{D}(\mathrm{mg} / \mathrm{l})$ & 0.0 & 0.01 & 0.05 & Mean of BA \\
\hline \multicolumn{6}{|l|}{ BA (mg/l) } \\
\hline 0.0 & & 0.0 & 0.0 & 0.0 & 0.0 \\
\hline 3.0 & & 0.1 & 1.5 & 3.3 & 1.63 \\
\hline 5.0 & & 0.2 & 2.4 & 4.5 & 2.37 \\
\hline 7.0 & & 2.8 & 4.3 & 7.4 & 4.83 \\
\hline Mean of 2,4-D & & 0.77 & 2.05 & 3.80 & \\
\hline LSD (0.05) & & $\mathrm{BA}=0.97$ & & $2,4-\mathrm{D}=0.84$ & $\mathrm{BA} * 2,4-\mathrm{D}=1.68$ \\
\hline
\end{tabular}




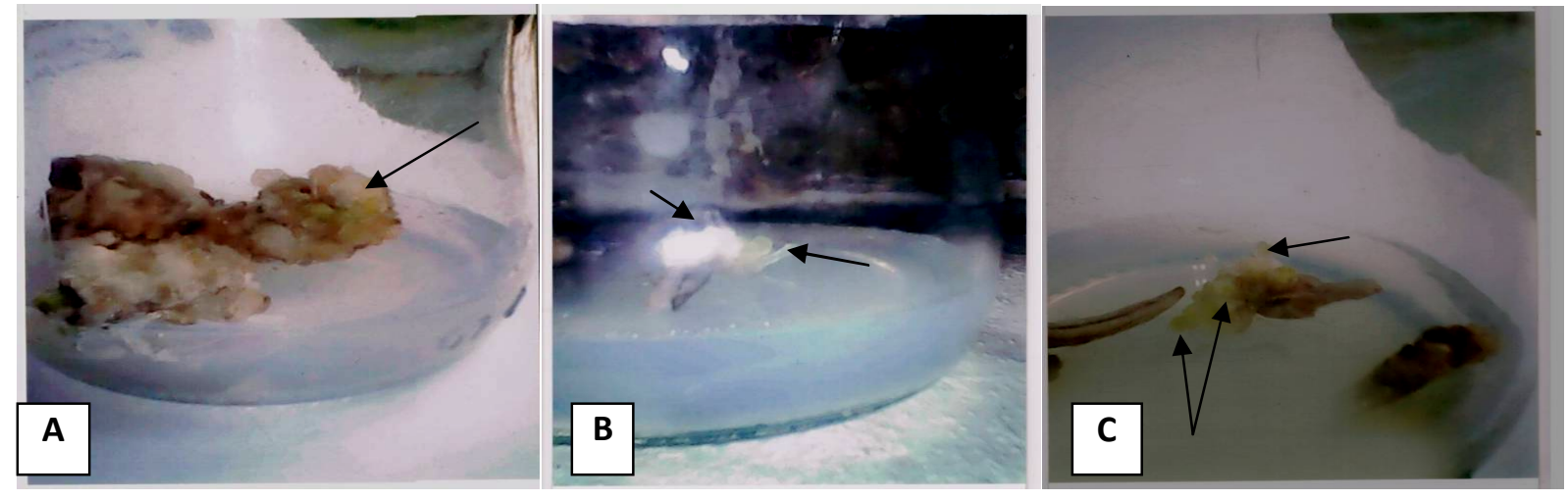

Fig. 3. Plantlets regenerated from anther cultures, (A) green swellings on callus, $(B, C)$ plantlets regeneration through callus (arrows) on medium with $7.0 \mathrm{mg} / \mathrm{l} \mathrm{BA}+0.05 \mathrm{mg} / \mathrm{l}$ 2,4-D and $5.0 \mathrm{mg} / \mathrm{l} \mathrm{BA}+0.05 \mathrm{mg} / \mathrm{l}$ 2,4-D.

Table 3. Influence of different concentrations of BA and 2,4-D (mg/l) in MS medium on catalase activity (unit) of different stages of callus and organogenesis in anthers cultures of Datura metel. L.

$\begin{array}{lllll}2,4-\mathrm{D}(\mathrm{mg} / \mathrm{L}) & 0.0 & 0.01 & 0.05 & \text { Mean of BA }\end{array}$

BA(mg/L)

\begin{tabular}{ccccc}
\hline $\mathbf{0 . 0}$ & 0.1 & 0.2 & 0.3 & 0.2 \\
$\mathbf{3 . 0}$ & 0.3 & 6.1 & 12.5 & 6.3 \\
$\mathbf{5 . 0}$ & 0.4 & 8.3 & 23.5 & 10.7 \\
$\mathbf{7 . 0}$ & 0.5 & 12.1 & 47.3 & 20.0 \\
Mean of 2,4-D & 0.3 & 6.7 & 20.9 & \\
LSD (0.05) & $\mathrm{BA}=15.50$ & \multicolumn{2}{c}{$2,4-\mathrm{D}=13.42$} & $\mathrm{BA} * 2,4-\mathrm{D}=26.85$ \\
\hline
\end{tabular}

The increasing in catalase activity in organogenic callus with regenerated plantletes is in agreement with Gupta and Datta (2003) and Meratan et al.( 2009) who referred in their studies that the greatest increasing in catalase activity of regenerated shoots than in callus and regenerated roots may suggest the enzyme effective scavenging mechanism to remove hydrogen peroxide that produced in regenerated shoots.

\section{Conclusion}

The present study revealed that the callus formation and organogenesis from callus cultures was dependent on plant growth regulators concentrations. Catalase may be used as a marker for organogenesis in Datura metel L. anther cultures.

\section{REFERENCES}

Alagumanian, S., P.V. Saravana, R. Balachandar, K.M. Rameshkannan and V. Rao (2004). Plant regeneration from leaf and stem explants of Solanum trilobatum L. Sci. Corresp., 86: 1478-1480.

Blokhina, O. (2000). Anoxia and oxidative stress: Lipid peroxidation, antioxidant status and mitochondrial function in plant. Academic Dissertation Thesis.

Brasileiro, A.C.R., L. Willadino, G.G. Carvalheira and M. Guerra (1999). Callus induction and plant regeneration of tomato (Lycopersicon esculantum cv.IPA 5) via anther culture. Cienc. Rural., 29. 
Frary, A., D. Gol, D. Keles, B. Okmen, H. Pinar, H. Osigva, A. Yemenicioglu and S. Doganlar (2010). Salt tolerance in Solanum pennellii: Antioxidant response and related QTL. BMC Biol., 10 : 58.

GentSas (2007). SAS/Stat User Guide for Personal Computer, SAS Institute Inane Cary, NC. USA.

Gumuscu, A.G., S. Cocus, S. Uranbeg, A. Pek, M.C. Kan and N.E. Arslan (2008). In vitro micro propagation of endangered ornamental plant (Neotchihatchewia isatidea (Boiss) Rauschert). Afr. J. Biotech., 7:234- 238.

Gupta, S.D. and S. Datta (2003). Antioxidant enzyme activities during in vitro morphogenesis of gladiolus and the effect of application of antioxidants on plant regeneration. Biol. Plant., 47:179-183.

Ibrahim, M.A., H.A. Al-Taha and A.A. Seheem (2013). Effect of cytokinin type and concentration, and source of explants on shoot multiplication of pineapple (Ananas comosus 'Queen') in vitro. Acta Agric. Slov., 101 (1): 15-20.

Ibrahim, M.A., A.M. Jasim and M.F. Abbas (2012). In vitro plant regeneration of Indian jujube (Ziziphus mauritiana Lamk.) cv. Zaytoni via indirect organogenesis. Acta Agric. Slov., 99 (1): 65-67.

Jain, S.M. and S.J. Ochatt (2010). Protocols For in vitro Propagation of Ornamental Plants. Springer Protocols. Humana Press.

Kadota, M. and Y. Niimi (2004). Production of triploid plants of Japanese pear (Pyrus pyrifolia Nakai) by anther culture. Euphytica., 138 (2): 141-147.

Kaviani, B., A.A. Hesar, A. Tarang, S.B. Zanjani, D. Hashemabadi and M.A. Rezae (2011). Callus introduction and root formation on the leaf micro-cuttings of Matthiola incana using $\mathrm{Kn}$ and NAA. Am. Eurasian J. Agric. Environ. Sci., 11 (3): 456-461.

Konieczy, R., A.K. Banas, E. Surowka, Z. Michalec, Z. Miszalski and M. LibikKonieczny (2014). Pattern of antioxidant enzyme activities and hydrogen peroxide content during developmental stages of rhizogenesis from hypocotyl explants of Mesembryanthemum crystallinum L. Plant Cell Rep., 33: 165-177.

Mannan, M.A., T.C. Sarker, M.T. Akhter, A.H. Kabir and M.F. Alam (2013). Indirect plant regeneration in aromatic rice (Oryza sativa L.) var. 'Kalijira' and 'Chinigura'. Acta Agric. Slov., 15: 473-497.

Martins, J.P.R., M. Pasqual, A.D. Martins and S.F. Ribeira (2015). Effects of salt and sucrose concentrations on in vitro propagation of Billbergia zebrina (Herbert) Lindley (Bromeliaceae). Aust. J. Crop Sci., 9 (1): 85-91.

Meratan, A.A., S.M. Ghaffari and V. Niknam (2009). In vitro organogenesis and antioxidant enzymes activity in Acanthophyllum sordium. Biolo. Planta., 53 (1): 5-10.

Mishra, R.R., M.L. Behera, D.R. Kumar and J. Panigrahi (2006). High frequency regeneration of plantlets from seedling explants of Asteracantha longifolia (L.) Nees. J. Plant Biotech., 8:27.

Murashige, T. and F. Skoog (1962). A revised medium for rapid growth and bioassays with tobacco tissue cultures. Physiol. Plant., 15: 473-497.

Murch, S.J., A.R. Alan, J. Cao and P.K. Saxena (2009). Melatonin and serotonin in flowers and fruits of Datura metel L. J. Pineal Res., 47 (3): 277-283.

Nurhidayah, T., R. Horn and T. Rocher (1996). High regeneration rates in anther culture of interspecific sun flower hybrids. Plant Cell Repo., 16: 167-173.

Palai, S.K., G.R. Rout, S. Samantaray and P. Das (2000). Biochemical changes during in vitro organogenesis in Zingiber officinale Rosc. J. Plant. Biol., 27:153.

Radhika, K., N. Sujatha and R.T. Nageshwar (2006). Thidiazuron stimulates adventitious shoot regeneration in different safflower explants. Biol. Pl., 50:174-179.

Sato, F., T. Hashimoto, A. Hachiya, K. Tamura, K.B. Choi and T. Morishige (2001). Metabolic engineering of plant alkaloid biosynthesis. Proc. Nat. Acad. Sci., 98:367372. 
Selvaraj, N., M. Vasudevan, M. Manickavasagam and A. Ganapathi (2006). In vitro organogenesis and plant formation in cucumber. Boil. Pl., 50: $123-126$.

Shahsavari, E., A.A. Maheran, N.A.A. Siti and M.M. Hanafi (2010). The effect of plant growth regulators on optimization of tissue culture system in Malaysian uplandrice. Afr. J. Biotech., 9 (14): 2089-2094.

Sudhersan, S. and J. Hussian (2003). In vitro clonal multiplication of multipurpose tree, Ziziphus spinachristi (L.) Desf. Turk. J. Bot., 27: 167-171.

Tian, M., Q. Gu and M. Zhu (2003). The involvement of hydrogen peroxide and antioxidant enzymes in the Process of shoot organogenesis of strawberry callus. Plant Sci., 165:701-707.

Whitaker, J.R., A.G.J. Voragen and D.W.S. Wong (2003). Handbook of Food Enzymol., Marcel Dekker, Inc.

Willekens, H., S. Chamnongpol, M. Davey, M. Schraudner, C. Langbratels, M. VanMntage, D. Inze and W. VanCamp (1997). Catalase is sink for $\mathrm{H}_{2} \mathrm{O}_{2}$ and is indispensible for stress defense in $\mathrm{C} 3$ plants. J. EMBO, 16 (16) : 4806-4816.

Zaidi, M.A., M. Narayanan, R. Sardana, I. Taga, S. Postel, R. Johns, M. McNulty, Y. Mottiar, J. Mao, E. Loit and I. Altosaar (2006). Optimizing tissue culture media for efficient transformation of different indica rice genotypes. Agron. Res., 4: 563-575.

\section{العلاقة بين نشوء الأعضاء من متك الادورة .Datura metel L وفعالية الكاتليز خارج الجسم الحي}

$$
\begin{aligned}
& \text { سهام عبدالرزاق سالم } \\
& \text { قسم الإنتاج النباتي - كلية المسيب للتنقية - جامعة الفرات الأوسط - العراق }
\end{aligned}
$$

تهرف الدراسة الحالية إلى التحري عن نأثثير التراكيز المختلفة لمنظمات النمو النباتية في إستحناث الكالس و استعادة

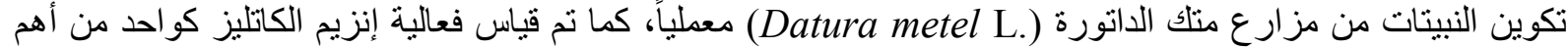

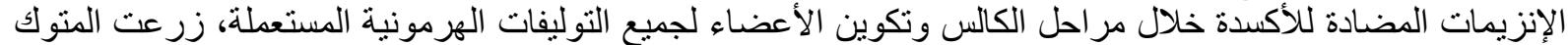

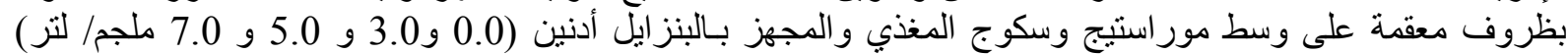

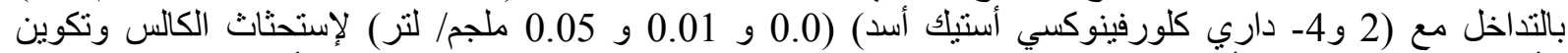

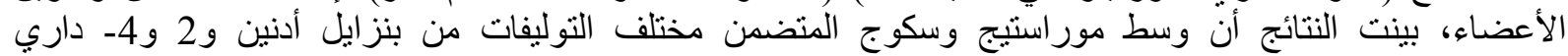

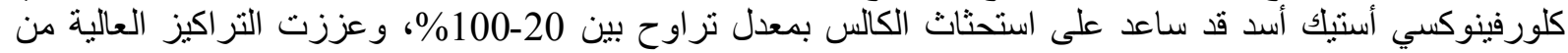

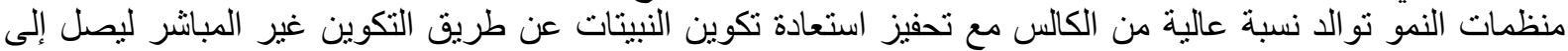

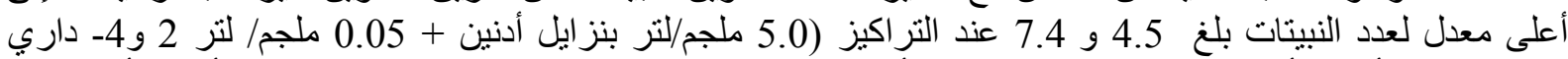

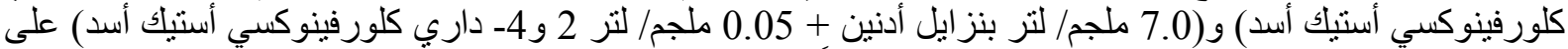

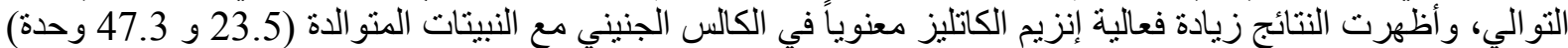

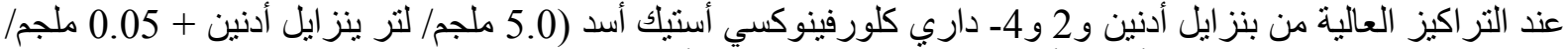

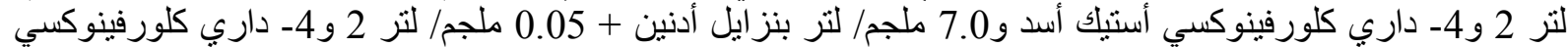

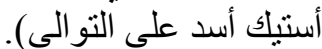

